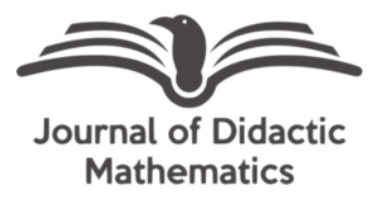

\title{
Peningkatan kemampuan berpikir logis dengan menggunakan metode pembelajaran kooperatif tipe team-accelerated instruction
}

\section{Dwi Maulida Sari*}

IAIN Padangsidimpuan, Padangsidimpuan, Sumatera Utara, Indonesia, 22733

\section{Rizky Nurul Hafni}

Sekolah Bangun Insan Mandiri, Medan, Sumatera Utara, Indonesia, 20235

*Corresponding Author: dwimaulida20@gmail.com

\begin{abstract}
This study is a quasi-experimental study with pretest-posttest one group design. The population in this study is all students majoring in mathematics education at an Asahan University, North Sumatra. Sampling was done by using the purposive sampling technique. Students work under the cooperative learning method Team-Accelerated Instruction (TAI) type. This research was conducted to study the enhancement of students' logical thinking ability after cooperative learning TAI types were implemented. The instruments used in this study are logical thinking ability tests, observation sheets, and student interviews. The data were analyzed by using t-test. From the result of data analysis, it is found that there is a significant enhancement in the logical thinking ability of the students' who work under the cooperative learning method TAI type. Therefore, cooperative learning Team-Accelerated Instruction (TAI) type can be alternative learning to improve students' logical thinking ability.
\end{abstract}

Historis Artikel:

Diterima: 15 Agustus 2020

Direvisi: 25 Agustus 2020

Disetujui: 30 Agustus 2020

\section{Keywords:}

Logical thinking skills;

Team-Accelerated

Instruction (TAI)

Sitasi: Sari, D. M., Hafni, R. N. (2020). Peningkatan kemampuan berpikir logis dengan menggunakan metode pembelajaran kooperatif tipe team-accelerated instruction. Journal of Didactic Mathematics, 1(2), 111-116. Doi: $10.34007 / \mathrm{jdm} . v 1 \mathrm{i} 2.317$.

\section{PENDAHULUAN}

Matematika adalah salah satu ilmu dasar yang berperan penting dalam upaya meningkatkan mutu pendidikan, penguasaan ilmu, perkembangan teknologi, serta mengembangkan daya pikir manusia. Untuk menguasai dan menciptakan ilmu dan teknologi di masa depan diperlukan penguasaan matematika yang kuat sejak dini. Oleh karena itu, matematika dipelajari di seluruh jenjang pendidikan dengan harapan dapat menumbuhkembangkan kemampuan dan pribadi siswa sejalan dengan tuntutan kehidupan di masa depan. Di Indonesia pelajaran matematika diberikan di setiap jenjang pendidikan sekolah dengan jam pelajaran yang memadai. Pentingnya pembelajaran matematika juga diperjelas dengan tujuan dari pembelajaran matematika dalam Permendiknas Nomor 22 tahun 2006. Dari tujuan pendidikan matematika yang diharapkan oleh pemerintah, kemampuan pemahaman, berpikir logis, pemecahan masalah dan komunikasi termasuk kemampuan yang diharapkan dapat berkembang setelah pembelajaran matematika diberikan.

Puskur (2002) menyatakan bahwa tujuan belajar matematika adalah mempersiapkan siswa untuk dapat menghadapi perubahan keadaan dalam kehidupan dan dalam dunia yang terus berkembang, melalui praktik yang didasarkan pada pemikiran logis, rasional, kritis, akurat, jujur, efisien dan efektif. Demikian pula Sitanggang (2010) menyatakan bahwa tujuan diadakannya pendidikan harus memperhatikan kebutuhan dan perubahan-perubahan yang berlangsung di masyarakat. Beberapa penjelasan tentang pentingnya mempelajari matematika tersebut menunjukkan bahwa kemampuan berpikir, termasuk di dalamnya kemampuan berpikir logis 
matematis perlu untuk ditingkatkan dalam proses belajar-mengajar. Peningkatan kemampuan berpikir logis tersebut akan melatih kemampuan siswa dalam memecahkan masalah matematis dan masalah dalam kehidupan sehari-hari serta akan membentuk kepribadian yang baik.

Dalam berpikir logis siswa dilatih untuk berpikir secara ilmiah agar dapat bertahan dalam keadaan yang selalu berubah, tidak pasti, dan semakin kompetitif (Iriani, 2014). Kemampuan berpikir logis juga memberi siswa kemampuan untuk memahami apa yang mereka baca atau pelajari, selain itu juga mendorong siswa untuk berpikir, mengemukakan hipotesis, mengembangkan hipotesis alternatif, dan menguji hipotesis mereka berdasarkan fakta yang diketahui, untuk menarik kesimpulan. Mengingat bahwa mahasiswa pendidikan matematika adalah calon pendidik matematika di masa depan yang akan mewujudkan tujuan pendidikan dalam mengembangkan dan memajukan pendidikan di Indonesia, mereka harus memiliki kompetensi yang diajukan oleh pemerintah. Seperti, memiliki pengalaman yang cukup, pengetahuan yang mumpuni, sikap yang baik dan benar agar mereka dapat melaksanakan proses belajar-mengajar dengan tepat yang akan berdampak kepada peningkatan prestasi, hasil belajar dan kemampuan matematis siswa.

Committee on the Undergraduate Program in Mathematics (CUPM, 2004) menyatakan bahwa pendidik harus bisa membantu siswa untuk mengembangkan pengetahuan yang kukuh, kemampuan berpikir dan kemampuan komunikasi, termasuk pengetahuan untuk berbagai macam penjelasan dan contoh, kemampuan berpikir kuantitatif dan logis yang baik dalam memisahkan dan menghubungkan kembali bagian komponen konsep dan metode. Sesuai dengan penjelasan sebelumnya menunjukkan bahwa berpikir logis penting untuk dikuasai oleh siswa, sehingga menuntut guru dan juga calon guru untuk memiliki kemampuan berpikir logis yang baik pula.

Tetapi kenyataan di lapangan menunjukkan bahwa kemampuan berpikir logis mahasiswa masih rendah. Dari hasil penelitian awal yang dilakukan oleh Sari (2018) di salah satu universitas di Asahan, ditemukan bahwa dari 28 siswa yang mengikuti tes kemampuan berpikir logis yang diberikan, hanya 5 orang yang bisa menjawab lebih dari 4 soal dengan jawaban yang belum sempurna, selebihnya hanya menjawab 1 atau 2 soal. Siswa merasa sangat sulit menyelesaikan persoalan dibagian pembuktian, serta memberikan alasan yang logis untuk jawaban mereka. Banyak siswa yang mengatakan bahwa mereka melupakan bagaimana menyelesaikan soal-soal sejenis. Hal ini disebabkan karena siswa terbiasa menghapal bagaimana bentuk penyelesaian suatu persoalan bukan bagaimana menyelesaikan suatu persoalan. Siswa juga mengatakan bahwa sulit untuk mengungkapkan alasan yang sesuai dan logis untuk jawaban yang mereka berikan. Banyak siswa merasa terbebani ketika mereka harus menyertakan alasan untuk solusi yang diberikan.

Hasil penelitian Suryanto dan Somerset (dalam Zulkardi, 2001) di beberapa sekolah menengah pertama di sebagian provinsi di Indonesia, menemukan bahwa hasil tes mata pelajaran matematika siswa sangat rendah, utamanya pada soal cerita matematika (aplikasi matematika). Hal ini sesuai dengan pendapat dari Saragih (2006) yang menyatakan rendahnya kemampuan siswa dalam penerapan matematika sampai saat ini masih mendapat keluhan, baik dari orang tua siswa maupun pakar pendidikan matematika, khususnya dalam penerapan di dalam kehidupan seharihari. Albrect (dalam Saragih, 2011) juga menyatakan bahwa kemampuan berpikir logis siswa masih rendah. Sebenarnya, sebahagian siswa sudah memiliki dasar pemikiran, artinya siswa tersebut sudah mengetahui langkah menyelesaikan masalah yang diajukan. Hanya saja siswa masih rendah pada bagian memiliki argumentasi dan menyimpulkan penyelesaian persoalan melalui penguatan argumentasi kepada dasar pemikiran, rendahnya hal ini dikarenakan kemampuan berpikir logis matematis mahasiswa masih rendah. Sebagai respons dari masalah rendahnya kemampuan berpikir logis siswa diperlukan suatu metode, pendekatan atau inovasi baru dalam pembelajaran matematika yang dapat merangsang kemampuan tersebut.

Mujis \& Reynold (2008) menyarankan dengan memberikan tanggung jawab kepada siswa dalam proses belajar-mengajar. Dari saran tersebut diharapkan dapat dibuat suatu kondisi kelas yang pelaksanaan proses belajar-mengajarnya dapat meningkatkan kemampuan berpikir logis. Metode atau pendekatan pembelajaran yang dianggap cocok memenuhi kedua syarat itu adalah 
Peningkatan kemampuan berpikir logis dengan menggunakan...

metode kooepratif tipe Team-Accelerated Instruction (TAI). Metode kooperatif tipe TeamAccelerated Instruction (TAI) diduga dapat meningkatkan kemampuan berpikir logis siswa karena metode ini merupakan stretegi pembelajaran yang melibatkan siswa berkolaborasi untuk mencapai tujuan bersama. Akibat positifnya adalah dapat mengembangkan hubungan antar kelompok, penerimaan terhadap teman sekelas yang lemah dibidang akademik, meningkatkan rasa harga diri (self-esteem) dan juga self-concept, selain itu juga menumbuhkan kesadaran berpikir, menyelesaikan masalah dan mengaplikasikan kemampuan dan pengetahuan mereka (Trianto, 2007). Oleh karena itu, pembelajaran TAI dianggap dapat meningkatkan kemampuan berpikir logis. Sesuai dengan tahap-tahap tipe TAI yang diungkapkan oleh Slavin (2008) yang dapat menunjang dan meningkatkan kemampuan berpikir logis adalah tes penempatan; membentuk kelompok heterogen; memberikan bahan ajar; belajar dalam kelompok; kelompok pengajaran; penilaian dan penghargaan kelompok; informasi materi esensial; tes formatif.

\section{METODE}

Penelitian ini adalah penelitian quasi experimental atau eksperimen semu dengan pendekatan kuantitatif. Penelitian kuasi eksperimen digunakan karena penelitian ini adalah penelitian untuk menimbulkan suatu keadaan atau kejadian, maknanya penelitian ini dilakukan dengan maksud melihat suatu akibat dari suatu perlakuan kepada suatu kelompok atau lebih (Sukardi, 2003; Arikunto, 2009). Pada studi ini subjek di kelompokkan secara acak. Untuk melihat apakah terdapat peningkatan kemampuan berpikir logis digunakan desain pretest-posttest one group design. Gliner, et al (2009) menyatakan bahwa pada desain ini setiap kelompok diukur sebelum diberikan perlakuan dan setelah diberikan. Tujuan dari desain ini adalah untuk memungkinkan peneliti mengevaluasi perbandingan perlakuan baru dengan perlakuan lama yang telah digunakan sebelumnya atau perlakuan baru lainnya.

Indikator kemampuan berpikir logis yang digunakan pada penelitian ini adalah: (1) menarik kesimpulan, perkiraan, dan interpretasi berdasarkan proporsi yang sesuai; (2) menarik kesimpulan atau membuat perkiraan dan prediksi berdasarkan peluang; (3) menarik kesimpulan, perkiraan dan interpretasi berdasarkan korelasi antara dua variabel; (4) membuktikan atau mengkonstruksi bukti; (5) menyusun analisis dan sintesis beberapa kasus; (6) analogi, menarik kesimpulan atau perkiraan berdasarkan keserupaan dua proses; dan (7) menetapkan kombinasi beberapa variabel. Kriteria yang digunakan untuk penilaian atau pemberian skor adalah seperti dijelaskan tabel dibawah ini:

Tabel 1. Kriteria Pemberian Skor Kemampuan Berpikir Logis

\begin{tabular}{cl}
\hline Skor & \multicolumn{1}{c}{ Kriteria } \\
\hline 4 & $\begin{array}{l}\text { Dapat menjawab semua aspek pertanyaan sesuai indikator kemampuan berpikir logis dengan } \\
\text { benar dan jelas atau tidak ambigu serta lengkap. }\end{array}$ \\
\hline 3 & $\begin{array}{l}\text { Dapat menjawab hampir semua aspek pertanyaan sesuai indikator kemampuan berpikir logis } \\
\text { dengan benar dan jelas atau tidak ambigu tetapi kurang lengkap. }\end{array}$ \\
\hline 2 & $\begin{array}{l}\text { Dapat menjawab sebagian aspek pertanyaan sesuai indikator kemampuan berpikir logis dengan } \\
\text { benar tetapi kurang jelas dan kurang lengkap. }\end{array}$ \\
\hline 1 & $\begin{array}{l}\text { Menjawab dengan tidak benar, tidak jelas atau ambigu dan kurang jelas aspek pertanyaan sesuai } \\
\text { indikator kemampuan berpikir logis. }\end{array}$ \\
\hline 0 & Tidak menjawab. \\
\hline
\end{tabular}

Selanjutnya setelah soal diujikan dan diberikan skor untuk setiap jawaban siswa, data dianalisis dengan melakukan uji hipotesis. Untuk melakukan pengujian harus memenuhi syarat untuk melaksanakan analisis data dalam melaksanakan uji hipotesis, yaitu uji normalitas dan uji homogenitas. Untuk pengujian hipotesis, dilakukan dengan menggunakan uji-t. Membandingkan nilai sig (2-tailed) yang ditemukan dengan persen error nya. Dengan hipotesis statistiknya:

Ho: Penggunaan metode pembelajaran TAI seacara signifikan tidak dapat meningkatkan kemampuan berpikir logis mahasiswa. 
Ha: Penggunaan metode pembelajaran TAI secara signifikan dapat meningkatkan kemampuan berpikir logis mahasiswa.

Jika, sig. $<0,05$, Ho ditolak

sig. $>0,05$, Ha ditolak.

\section{HASIL DAN PEMBAHASAN}

Penelitian ini bertujuan untuk melihat peningkatan kemampuan berpikir logis matematis mahasiswa yang memperoleh pembelajaran Team- Accelerated Instruction (TAI). Pada penelitian, tes dilakukan sebanyak 2 kali, yaitu pada sebelum pembelajaran (pretes) dan setelah pembelajaran (postes). Untuk lebih melengkapi data juga dilakukan observasi terhadap aktivitas mahasiswa, untuk melihat respons mahasiswa pada saat pembelajaran terhadap jawaban tes melakukan wawancara terbatas dengan beberapa mahasiswa. Hal tersebut dilakukan untuk menarik kesimpulan penelitian ini semakin menyeluruh. Analisis data dalam penelitian ini diolah dengan bantuan software Microsoft Office Excel dan SPSS.

Tabel 2. Hasil Tes Kemampuan Berpikir Logis

\begin{tabular}{lccccccc}
\hline \multirow{2}{*}{ Kelas } & \multirow{2}{*}{$\mathrm{n}$} & \multicolumn{2}{c}{ Pretes } & \multicolumn{2}{c}{ Postes } & \multicolumn{2}{c}{ N Gain } \\
\cline { 3 - 9 } & & $\bar{X}$ & SB & $\bar{X}$ & SB & $\bar{X}$ & SB \\
\hline Kelas TAI & 23 & 1,96 & 0,64 & 25,26 & 1,18 & 0,90 & 0,04 \\
\hline Nilai Maksimal Ideal & \multicolumn{2}{c}{28} & \multicolumn{2}{c}{28} & & 1 \\
\hline
\end{tabular}

Tabel 2 menyajikan statistik deskriptif nilai pretes, postes, dan n-gain kemampuan berpikir logis matematis mahasiswa. Pada Tabel 2 terlihat rata-rata kemampuan berpikir logis mahasiswa meningkat degan baik. Peningkatan nilai rerata dari pretes dan posttest tidak menggambarkan peningkatan kemampuan lebih baik, nilai n-gain menggambarkan kondisi peningkatan kemampuan berpikir logis mahasiswa setelah menerima pembelajaran TAI. Nilai rata-rata peningkatan kemampuan berpikir logis mahasiswa termasuk dalam peningkatan dengan kategori tinggi sebagaimana kriteria peningkatan n-gain yang dinyatakan oleh Hake (1999).

Walau demikian belum dapat disimpulkan bahwa peningkatan kemampuan berpikir logis tersebut secara signifikan meningkat. Untuk itu diperlukan uji lanjutan untuk memastikan dengan menggunakan pembelajaran TAI secara signfikan meningkatkan kemampuan berpikir logis mahasiswa. Untuk itu dilakukan uji hipotesis untuk memastikan peningkatan tersebut secara siginifikan. Dengan menggunakan SPSS dilakukan uji t, ditemukan hasil:

Tabel 3. Hasil Uji Kemampuan Berpikir Logis Mahasiswa

\begin{tabular}{|c|c|c|c|c|c|c|}
\hline & \multicolumn{6}{|c|}{ Test Value $=0.5$} \\
\hline & \multirow[b]{2}{*}{$\mathrm{T}$} & \multirow[b]{2}{*}{ Df } & \multirow[b]{2}{*}{ Sig. (2-tailed) } & \multirow{2}{*}{$\begin{array}{c}\text { Mean } \\
\text { Difference }\end{array}$} & \multicolumn{2}{|c|}{$\begin{array}{l}\text { 95\% Confidence Interval of the } \\
\text { Difference }\end{array}$} \\
\hline & & & & & Lower & Upper \\
\hline n_gain & 45.699 & 22 & .000 & .3966783 & .378677 & .414680 \\
\hline
\end{tabular}

Pada Tabel 3 terlihat nilai Sig. (2-tailed) yang diperoleh adalah 0,000 atau nilai Sig. lebih kecil dari $\alpha$. Berdasarkan kriteria pengujian, maka Ho ditolak atau dengan kata lain dapat disimpulkan bahwa Penggunaan metode pembelajaran TAI secara signifikan dapat meningkatkan kemampuan berpikir logis mahasiswa.

Peningkatan ini dapat diperjelas melalui proses menjawab mahasiswa dan juga melalui wawancara. Pada soal nomor 1 dengan aspek berpikir logis analogi: menarik kesimpulan atau perkiraan berdasarkan keserupaan dua proses. Seluruh mahasiswa menjawab dengan benar. Pada jawaban mahasiswa terlihat mereka memilih menggunakan teorema dibanding menggunakan 
Peningkatan kemampuan berpikir logis dengan menggunakan...

definisi untuk membuktikan bahwa irisan kedua ideal adalah sebuah ideal pula, hal ini mungkin disebabkan oleh kebiasaan mereka untuk memilih cara yang dipahami dalam mengerjakan suatu soal. Pada saat proses pembelajaran mahasiswa berusaha untuk membuktikan teorema sementara definisi sudah tersedia, sehingga sepertinya mereka lebih mengingat apa yang sudah mereka usahakan untuk kerjakan dan pahami dibanding apa yang diberikan kepada mereka. Hasil wawancara kepada mahasiswa yang mendapatkan peningkatan kemampuan berpikir logis yang paling tinggi di kelas TAI mengatakan bahwa dia mengingat cara tersebut karena ketika mengerjakan lembar aktivitas (LA) yang pertama dikerjakan adalah membuktikan teorema uji ideal, sehingga syarat uji ideal lebih diingat ketimbang syarat yang diberikan oleh definisi.

Pada soal nomor 2 dengan aspek berpikir logis menetapkan komposisi dari beberapa variabel. Hanya sedikit mahasiswa yang menjawab dengan benar dan tepat. Mahasiswa menggunakan alasan logis yang mendukung penetapan komposisi dari beberapa variable dibandingkan dengan menggunakan tabel cayley. Hal ini mungkin disebabkan karena ketika mahasiswa TAI menyampaikan materi tentang ideal prima atau ideal maksimal mereka menjelaskan menggunakan alasan dan fakta yang mendukung jawaban mereka dibanding dengan tabel cayley. Dengan metode ini akan membantu mereka ketika soal yang diberikan dalam bentuk interval atau data yang sangat banyak. Kesalahan yang timbul banyak mahasiswa yang menentukan hanya salah satu dari pertanyaan yang diberikan. Padahal seharusnya mereka menentukan kemungkinan untuk kedua pertanyaan sehingga mereka mampu mengkomposisikan ideal tertentu dapat berupa ideal prima maupun ideal maksimal.

Dari keseluruhan hasil analisis statistik, observasi dan juga wawancara kemampuan berpikir logis mahasiswa yang diajarkan dengan menggunakan TAI meningkat dengan baik. Hal ini mungkin terjadi karena tahapan belajar pada kelas TAI lebih banyak melatih kemampuan berpikir logis, mahasiswa dilatih soal-soal berpikir logis sebanyak tiga kali pada pertemuan pertama dan dua kali pada pertemuan kedua melalui soal penempatan, LA maupun soal tes individu. Kemudian, pada kelas TAI tahap diskusi lebih lama dibanding belajar individu. Tahap ini dapat membantu mahasiswa mengembangkan kemampuan berpikir logisnya melalui tukar pendapat baik pada saat diskusi maupun pada saat menampilkan hasil diskusi. Selain tahap-tahap pada pembelajaran mahasiswa juga dibantu memahami materi melalui pengerjaan LA yang melatih siswa untuk menarik kesimpulan, perkiraan atau interpretasi berdasarkan proporsi yang sesuai, menarik kesimpulan atau perkiraan berdarkan korelasi antara dua variabel, menetapkan kombinasi dari beberapa variabel, membuktikan atau mekonstruksi bukti, melakukan analogi maupun menyusun analisis dan sintesis beberapa kasus. Sehingga mampu memaksimalkan kemampuan berpikir logis mahasiswa.

Hal ini disetujui oleh mahasiswa melalui hasil wawancara yang dilakukan. Mahasiswa pada kelas TAI berkata bahwa sebelumnya dia sangat susah memahami materi mata kuliah matematika universitas termasuk struktur aljabar didalamnya, dia merasa dia tidak akan pernah bisa memahami bagaimana cara membuktikan teorema yang diberikan, tetapi ternyata melalui pembelajaran TAI dia membuktikan bahwa ketika dia mau berusaha lebih maupun memusatkan pikirannya untuk belajar maka dia mampu melakukannya. Mahasiswa tersebut juga mengatakan bahwa melalui belajar individu dan kelompok dia mengetahui bahwa dirinya lebih bisa paham bila belajar dalam kelompok kecil, tidak dalam suasana kelas pada umumnya, dimana jika tidak dosen yang mengajar maka teman dari kelompok lain yang mempresentasiakan sehingga mengakibatkan keaktifan dikelas hanya terjadi diantara mahasiswa yang ingin aktif saja.

\section{KESIMPULAN}

Peningkatan kemampuan berpikir logis mahasiswa yang diajarkan dengan menggunakan metode pembelajaran kooperatif tipe Team Accelerated Instruction (TAI) mengalami peningkatan yang signifikan. Rerata peningkatan kemampuan berpikir logis mahasiswa dalam kategori tinggi. Oleh karena itu, metode pembelajaran kooperatif tipe Team Accelerated Instruction (TAI) dapat digunakan sebagai salah satu metode pembelajaran rujukan dalam melaksanakan pembelajaran 
dikelas.

\section{DAFTAR PUSTAKA}

Arikunto, S. (2009). Manajemen penelitian. Jakarta: PT Rineka Cipta.

Committee on the Undergraduate Program in Mathematics atau CUPM. (2004). Undergraduate programs and courses in the mathematical science: CUPM Curriculum Guide 2004. Washington, DC: The Mathematical Association of America.

Gliner, J. A., \& Morgan, G. A. (2009). Research method ins in applied settings. United Kingdom: Taylor $\&$ Francis e-Library.

Iriani, W. (2014). Peningkatan kemampuan berpikir logis matematis dan kemandirian belajar siswa smp melalui pembelajaran kooperatif tipe team assisted individualization dengan pendekatan open ended. Tesis SPs UPI Bandung: Tidak diterbitkan

Muijs, D., Reynolds, D. (2008). Effective teaching. Yogyakarta: Pustaka Pelajar.

Puskur. (2002). Kurikulum dan hasil belajar. kompetensi dasar mata pelajaran matematika sekolah dasar dan madrasah ibtidaiyah. Jakarta: Depdiknas.

Saragih, S. (2006). Menumbuh kembangkan berpikir logis dan sikap positif terhadap matematika melalui pendekatan matematika realistik: Jurnal pendidikan dan kebudayaan Departemen Pendidikan Nasional, Badan Penelitian dan Pengembangan, 1-21.

Saragih, S. (2011). Penerapan pendekatan pembelajaran matematika realistik dan kelompok kecil untuk meningkatkean kemampuan keruangan, berpikir logis,dan sikappositif terhadap matematika siswa kelas VIII. Disertasi pada PPs UPI: Tidak Diterbitkan.

Sari, D. M, dkk. (2018). Analysis of students' prior ability in mathematical logical thinking ability. Advanced Journal of Technical and Vocational Education, 2(1), 13-18.

Sitanggang, A. K. (2010). Upaya meningktkan kemampuan berpikir logis dan kemampuan komunikasi matemastis siswa smp melalui pembelajaran matematika realistik. Tesis UNIMED: Tidak Diterbitkan.

Slavin, R. E. (2008). Cooperative learning teori, riset dan praktik. Bandung: Nusa Media.

Sukardi. (2003). Metodologi penelitian pendidikan; kompetensi dan praktiknya. Jakarta: Bumi Aksara.

Trianto. (2007). Mendesain model pembelajaran inovatif-progresif. Surabaya. Kencana Prenada Media Group.

Zulkardi. (2001). Realistic mathematics education (rme). teori, contoh pembelajaran dan taman belajar di internet. Makalah. UPI Bandung. 